\title{
Pipeline Geopolitics: Subaquatic Materials and the Tactical Point
}

Andrew Barry and Evelina Gambino

Department of Geography, UCL, Gower St, London, WC1E 6BT

a.barry@ucl.ac.uk

Final accepted ms, forthcoming in Geopolitics, 2019

\begin{abstract}
This paper starts from the proposition that studies of geopolitics need to address the political significance of spaces above and below the apparently two-dimensional or flat surface of the land and sea. However, we depart from the view that such spaces should be defined by their verticality or conceived as three-dimensional volumes. Instead, the argument stresses the importance of attending to the relations between physical and biological things, and the ways in which the proximity of things is both mediated and supplemented by legal, and scientific and political practice. The empirical focus of the paper is a specific geopolitical puzzle. How did a short section of the route of a transnational gas pipeline, the $3500 \mathrm{~km}$ Southern Gas Corridor, come to be a site or 'tactical point' at which the construction of the pipeline could be disrupted? Our contention is that any analysis of this political question must address not only the contested relations between states, corporations and civil society, but also the potential tension and interference between the horizontal networked geopolitics of pipelines and their subaquatic and subterranean construction. The subaquatic turns out not to be volume but a space of situated encounters between disparate materials.
\end{abstract}




\section{Introduction}

Transnational oil and gas pipelines would appear to be a perfect manifestation of a horizontal vision of geopolitics. Indeed, the construction of such massive energy infrastructures seems to both embody and forge strategic connections, alliances and dependencies between states. But while transnational pipelines are often conceived as horizontal networks, they are also frequently built underground. They are laid in trenches and tunnels, cutting underneath the surface of earth and sea. Once constructed they exist more or less invisibly, just beneath the surface or 'visibly invisible': invisible to the eye but intensely visible in the form of an archive of documents that are simultaneously expected to record and anticipate their environmental and social impact (Barry 2015).

In this paper, we suggest that there is an unacknowledged tension between the horizontal 'networked' geopolitics and economy of pipelines, which is widely recognised, and their subterranean and subaquatic formation, which is not. It may be easy to plot oil and gas pipeline routes in two dimensions on a map, and to imagine a transnational network as a connection between points. But pipeline construction also engages the presence of a range of subterranean and subaquatic things - including rock formations, aquifers and sources of mineral water, zones of earthquake and landslide risk, archaeological remains and marine species - with which pipelines co-exist. Rather than regard these subsurface things as merely incidental, we argue in this paper that there is a need to understand why, where and when subsurface materials acquire geopolitical consequence (Barry 2013, Valdivia 2015). These questions have become increasingly important in the context of wider debates about the relation between investments in new energy 
infrastructures, including pipelines, and the politics of transition to a post-carbon economy.

Our argument is both empirical and conceptual. Empirically, we focus on the development of the Trans Adriatic gas Pipeline (TAP), which forms one element of the Southern Gas Corridor that is projected to run between the Caspian Sea and Southern Italy. We demonstrate why and how a short section of this pipeline route in Italy came to have remarkable geopolitical and economic significance: how, for a period of time, it became what we term a 'tactical point' in the network, ${ }^{1}$ a site in which the construction of the pipeline could be disrupted. Conceptually, the paper addresses the limitations of two ways of conceiving of the geopolitics of the subterranean and the subaquatic, and proposes a third approach. On the one hand, we question the idea that the subsurface should be understood as a 'volume' that needs to be secured or occupied. We argue that a focus on 'volume' fails sufficiently to consider the relations between disparate materials - including, in this case, water, sand, concrete, steel and seagrass - which make up subsurface spaces. ${ }^{2}$ On the other hand, while our analysis stresses the geopolitical significance of subsurface materials and processes, we also depart from those approaches to materialism that fail to pay sufficient attention to political, scientific and legal practices, and to history. Our contention is that the subsurface can be understood as a space of dynamic relations and interferences between disparate materials that are increasingly supplemented and mediated by scientific practice and the law (Barry 2013: 183, Kama 2013). Through the case of the TAP in Southern Italy, we argue that it is both the presence of subsurface materials and their scientific and legal mediation that contribute to the constitution of a critical tactical point in the Southern Gas Corridor. 


\section{The Trans Adriatic Pipeline}

In March 2017 we attended a small rally in the Italian seaside resort of San Foca situated on the Adriatic coast south of Brindisi, approximately $25 \mathrm{~km}$ from Lecce, in the municipality of Melendugno in the Salento. Behind the speakers lay a harbour full of small yachts, a $16^{\text {th }}$ century guard tower, a tourist information kiosk, and a sheet covered with small leather items for sale. Some of the participants in the rally left to buy an ice cream on the other side of the coastal road, while others chatted on the sea front. This setting might seem an unlikely location for a geopolitical dispute. Yet at the rally speakers demonstrated their opposition to the construction of the Trans Adriatic gas Pipeline (TAP), which is projected to run across northern Greece, Albania and the Adriatic, before connecting to the Italian pipeline system near the village of Melendugno, a few kilometres inland from San Foca. The pipeline was planned to form the last stage of the Southern Gas Corridor along which gas is expected to flow directly from the Caspian Sea to Europe.

Speakers at the San Foca rally told those present about the relations between the Italian state and the south, the authoritarianism of Azerbaijan, the attachment of local people to their land, the role of the European Investment Bank in the TAP project, the declining demand for gas in Italy, and the importance of tourism to the region's economy. One of the leaders of NoTAP, the coalition of mainly local groups that opposed the construction of the pipeline in the municipality, suggested that the struggle had reached a critical moment. NoTAP posters, flags and graffiti were scattered across San Foca and neighbouring villages, while approximately $2 \mathrm{~km}$ inland a small 
occupation of an ancient olive grove had occurred near the projected route of the pipeline. Widely reported in the national press, images of wrapped olive trees waiting to be removed in order to make it possible to begin construction, enclosed by security fences, made a striking contrast to the image of the small camp of protestors. During the rally, speakers advised those who could to support the occupation over the coming days. $^{3}$

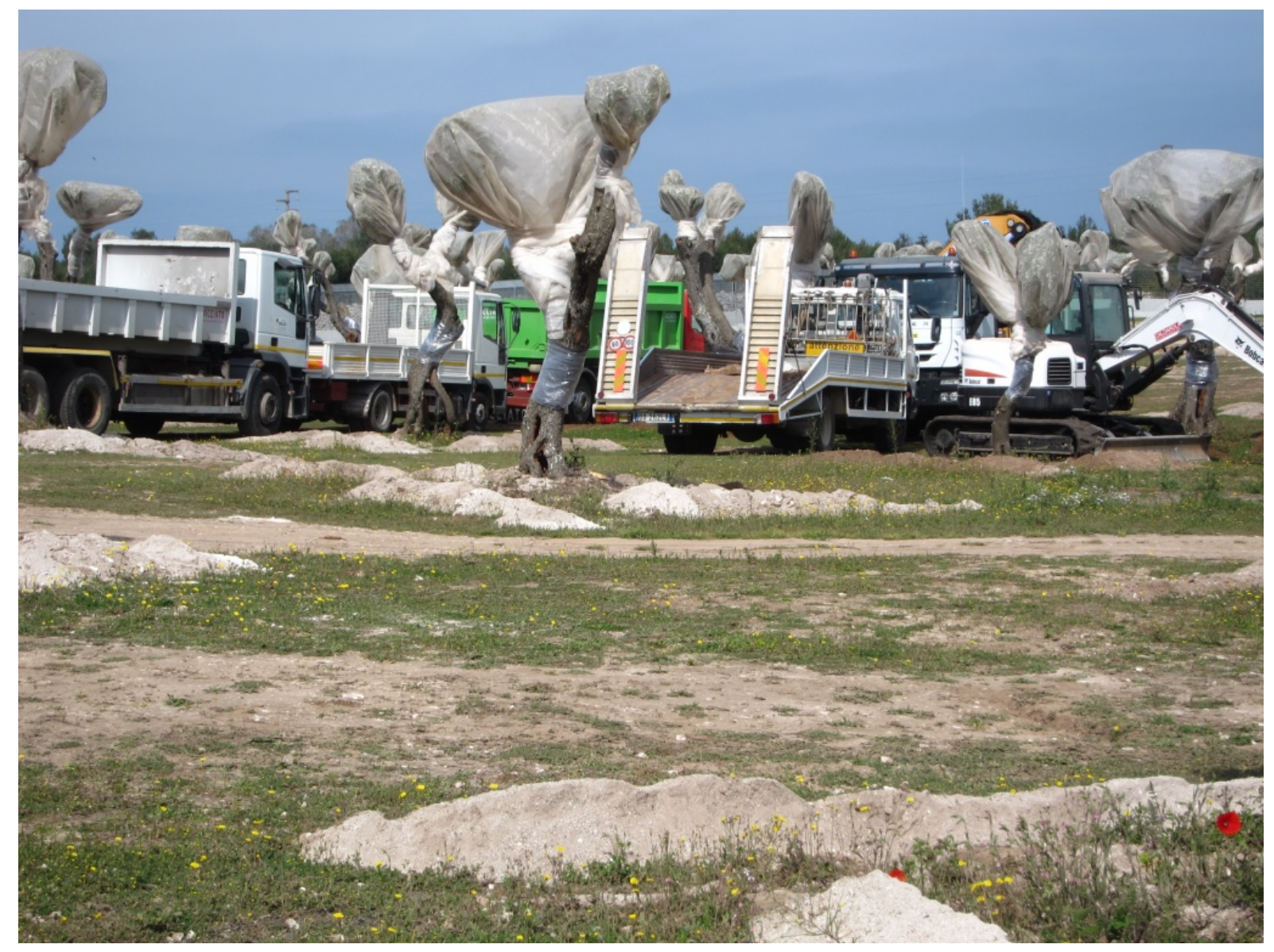

Fig 1: Wrapped olive trees, in the vicinity of Melendugno, April 2017, photo: Andrew Barry. 


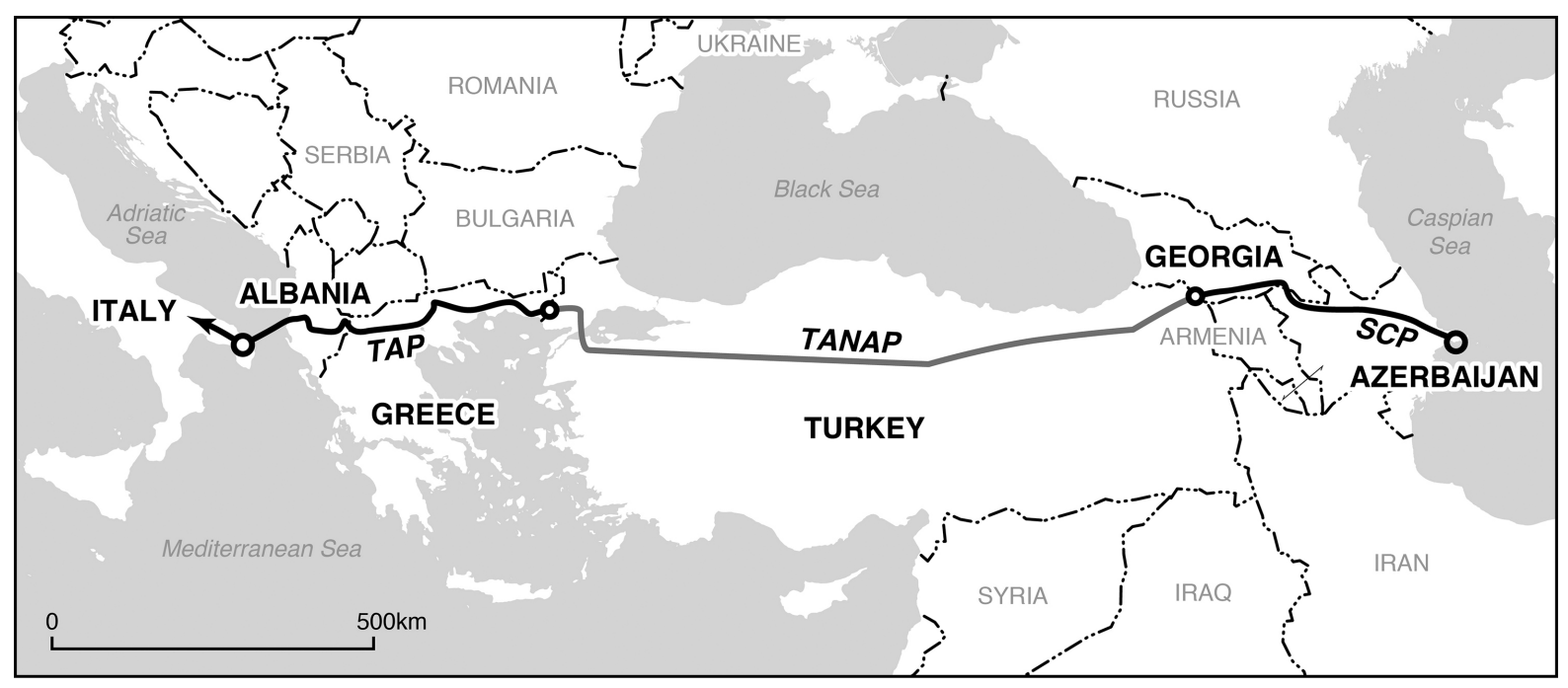

Fig 2: Route of the Southern Gas Corridor, including TAP, drawing by Miles Irving, Department of Geography, UCL.

One of the reasons that the construction of the pipeline should be prevented, according to many of its opponents, was that it would impact negatively on typical features of the traditional landscape of the Salento, including olive trees and dry stone walls (TAP 2014c). But as we will show, while the construction of the pipeline underneath the olive grove of Melendugno came to be the focus for both the mass media and the occupation, it is not possible to understand why San Foca, in particular, became so geopolitically significant without also considering the subaquatic construction of the pipeline including its proximity to meadows of seagrass that are to be found offshore along the Adriatic coast.

The TAP was projected to become the final element of a $3500 \mathrm{~km}$ pipeline system that, when complete, would also include the Trans Anatolian Pipeline across Turkey and the South Caucasus Pipeline (SCP) across Azerbaijan and Georgia. According to its proponents, the construction of the Southern Gas Corridor would help address a 
geoeconomic problem that had become apparent during the Russia-Ukraine gas dispute of 2009, which saw the suspension of Russian gas exports to Europe (Pirani et al 2009, European Parliament 2009, Bosse 2011, Bouzarovski et al 2015, Siddi 2017, Wilson 2014). The pipeline would thus, it was claimed, make a contribution both to the maintenance of energy security and to the consolidation of a competitive European gas market (TAP 2014b, 9), while also enabling the transition from a carbon to a post-carbon economy. All of these claims about TAP's strategic significance can be contested, and indeed were contested by the members of NoTAP. More broadly, as Kärg Kama (2016, 833) has argued, the concept of 'energy security' is both dynamic and multi-faceted, while 'transition represents a highly contextual and contested process', as it was in the case of TAP. Nonetheless, a month prior to the rally on San Foca beach, the VicePresident of the European Commission, Maroš Šefčovič, had formulated this bold vision of the future, anticipating the effects of the Southern Gas Corridor at a ministerial meeting in Baku: ${ }^{4}$

By 2020, we will have gas flowing through the Southern Gas Corridor to Europe, further diversifying our energy supplies. Building the Energy Union is not an end in itself. It is a huge modernisation programme for Europe, benefiting young Europeans, entrepreneurs and mayors across the continent (European Commission 2017).

In early 2017, the controversy centred on Melendugno had become an unexpected obstacle to these wider strategic ambitions. Press reports of the ministerial meeting in Baku at which Šefčovič spoke noted that the progress of the project along the short section of the route between San Foca and Melendugno had been slow. This delay 
potentially posed a problem for TAP's investors as contracts had already been signed for the delivery of gas in 2020. Moreover, the EU had granted TAP an exemption from a requirement to give third party access to the pipeline, but this exemption could expire, thus undermining the financial viability of the project (European Commission 2015, see also Makholm 2012). Given this timescale, the Italian government felt the need to reassure both the Azerbaijan government and international investors that the project would be delivered on time and that the opposition to the project manifest in San Foca would be overcome. Thus, according to a Reuters report in February 2017, "Italian Industry Minister Carlo Calenda [had] said that work to clear a major hurdle to establishing TAP's landing point in southern Italy - a grove of more than 200 ancient olive trees - would begin on Monday" (Reuters 2017, our emphasis, see also Shiriyev 2017). While speakers at the San Foca rally spoke critically about Azerbaijan, participants at the ministerial meeting in Baku were equally aware of the significance of Melendugno and the obstacle that it potentially posed to the ministers' desire to complete the project on schedule. Shortly after the March rally on the San Foca seafront, a heavy police presence enabled the company to clear the remaining olive groves, thereby making it possible for construction work to begin. ${ }^{5}$

Michael Watts has argued that "what is distinctive about oil is that there are certain tactical points for holding up the supply of oil" (Watts 2004, 53, see also Mitchell 2011). Here we focus on gas rather than oil, and the construction of infrastructure rather than supply; but the concept of the tactical point remains a useful one and we develop it further here. It suggests that certain key locations have a greater potential to become tactical points than others, and that the disruption of oil and gas infrastructures does not occur everywhere but is highly localised. The concept of the tactical point therefore 
raises the question of how and why specific locations have the potential to become sites of disruption in principle and how they become so in practice. By 2017 Melendugno and San Foca had become just such a tactical point, one at which the construction of what was said to be a vital component of the EU energy network was being disrupted, which could hold up the supply of gas from the Caspian Sea in the future.

In this paper we propose that attention to the underground and undersea construction of pipelines helps us to answer a political geographical puzzle. If Puglia and the Salento had become implicated in debates about the EU's energy security, the question arises as to why San Foca had become, rather than any number of other coastal towns, the point at which TAP would cross the Italian coast, and thus have the potential to become a tactical point. Why had neither the industrial port of Brindisi, 60km north of San Foca on the Adriatic coast, nor the nearby town of Otranto been selected as alternatives? (TAP 2014d, 7) Why had San Foca emerged as the location at which TAP entered the Italian mainland, thus becoming a location that subsequently came to generate an intense level of friction to globalising logics? (Tsing 2005) One of our aims in this paper is therefore quite modest. By focusing on the subsurface construction of TAP we intend to show both how and why this location became part of the Southern Gas Corridor and how subaquatic things came to have unanticipated geopolitical significance. We do not discuss the debates about EU energy security or the European Energy Union or the material geography of the European gas sector in general (Bouzarovski et al 2015, 217). Although we expand in some detail on the relation between the controversy surrounding the construction of TAP and recent tendencies in Italian politics, we do not examine the longer history of environmental and infrastructural politics in Italy. Indeed, as the work of political ecologists suggests, another analysis of this dispute might pursue further the 
relation between the opposition to TAP and long-standing conflicts over questions of regional identity, state power, and economic and ecological justice in Italy (Peet and Watts 2004, Heynen and Van San 2015, Watts 2004). ${ }^{6}$

Our contention in this paper is that neither an analysis of the wider geopolitics of EU energy security nor an account of the shifting relations between the state, corporations and social movements in Italian politics can, on their own, explain either why San Foca and Melendugno had become been part of the pipeline system and, therefore, a possible tactical point. In arriving at this conclusion we were informed by the politico-legal and scientific practices of NoTAP. These practices rendered visible the proximity and interference between the subsurface infrastructure of the pipeline and its immediate physical environment. Hence, participants in the protest referred inter alia to the threat posed by pipeline construction to olive trees and dry stone walls, to groundwater, to the difficulty of constructing a microtunnel underneath the beach at San Foca, and above all to the presence and significance of a protected species of underwater seagrass, Posidonia Oceania, immediately off the coast. These concerns became strikingly evident through fieldwork. For example, on our first visit to the site of pipeline construction, an activist took us to inspect a hole in the ground through which we could see signs of the underground aquifer that supplied water to the olive groves. And in the village of Martano, $17 \mathrm{~km}$ from San Foca, we found that the municipality had printed posters that affirmed the importance of olive groves to the landscape and heritage of the Salento, while also highlighting the significance of seagrass and marine protected areas to both the region and the politics of TAP: as the posters declared, 'Posidonia habitat marino prioritario' [Posidonia priority marine habitat]. 


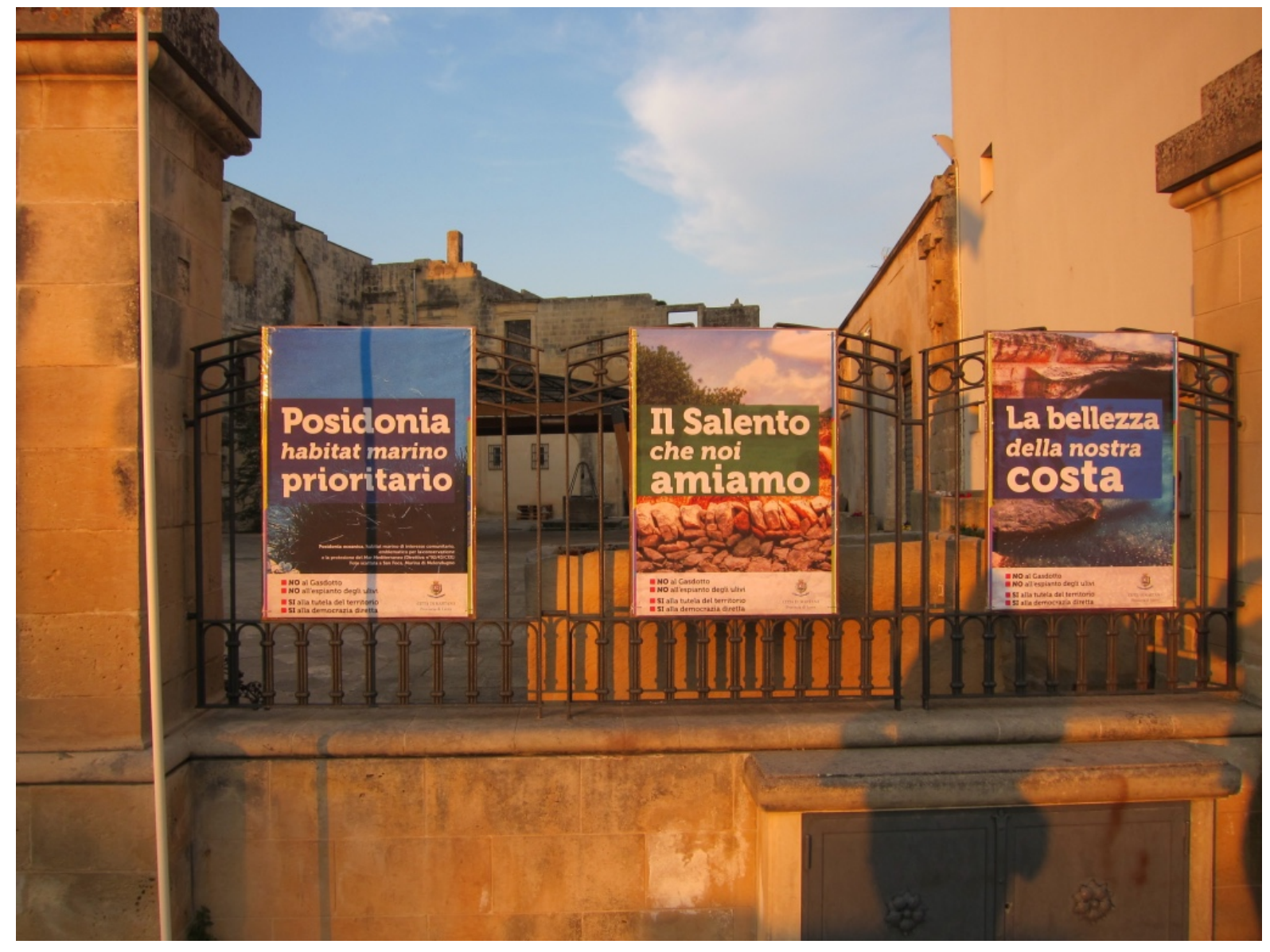

Fig 3: Posidonia habitat marino prioritario, Martano, Puglia, March 2017, photo:

Andrew Barry. 


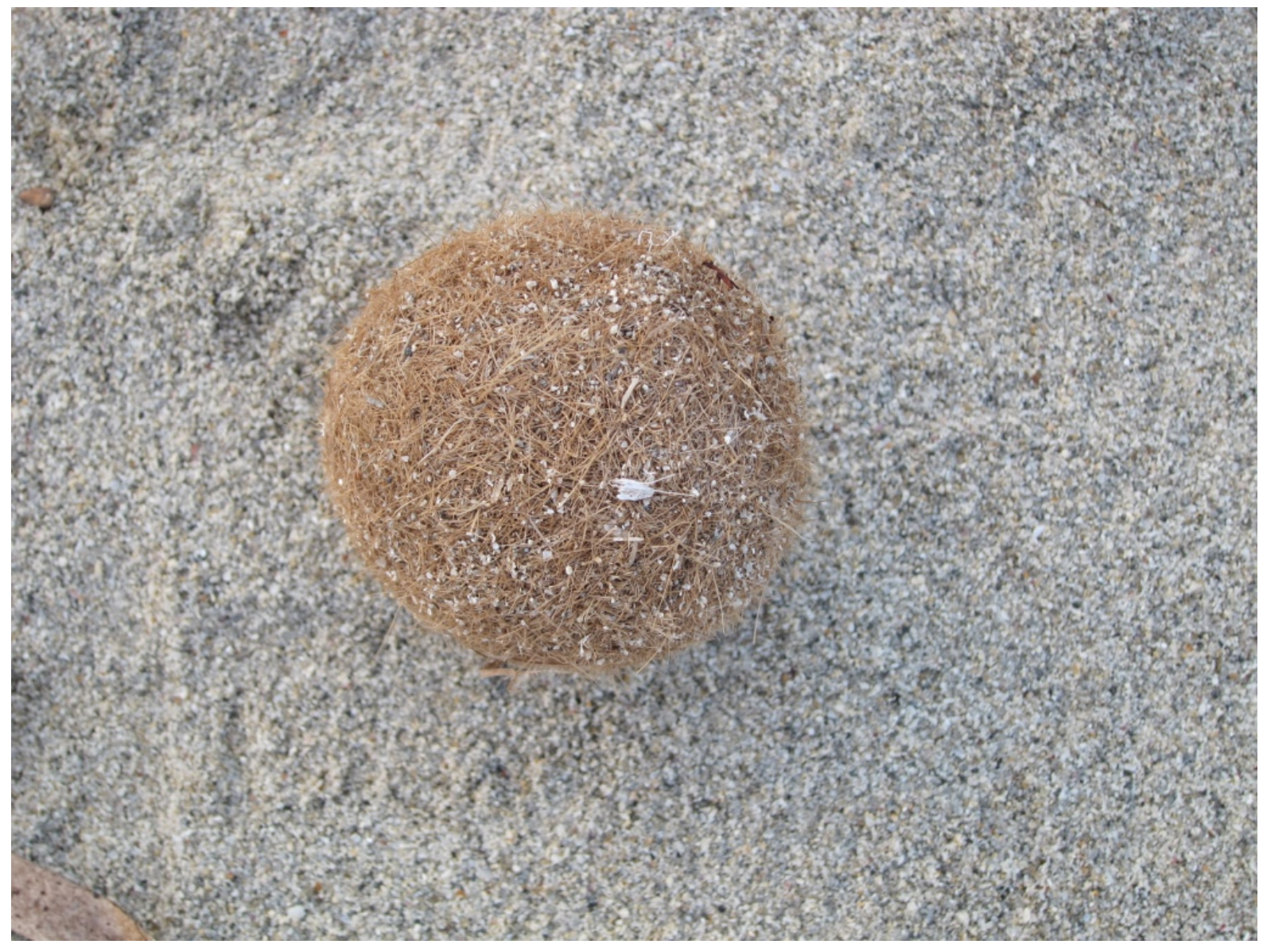

Fig 4: Ball of Posidonia on San Foca beach, March 2017, photo: Andrew Barry.

Our argument proceeds in three stages. First, we review the existing literature on the subterranean and the subaquatic. We consider the strengths and limitations of approaches that conceive of the subsurface as a 'volume' as well as those that focus on the liveliness of materials, and we advance a series of new arguments. Second, we discuss the relation between the TAP controversy and tendencies in Italian government and politics in the period prior to 2017 . We interrogate how and why the subaquatic came to matter politically in this particular case, and dwell on why the pipeline came to be constructed at this location on the Adriatic coast. Third, we address how the relation between TAP and the disparate organisms and materials of the subsurface came to be mediated and supplemented by scientific, legal and political practices. As we contend, 
the TAP controversy was both a dispute about the legality of pipeline construction in a specific location and a dispute about 'legality' in general. The intensity of the protest at Melendugno was a manifestation of tendencies in Italian politics, but it was also a controversy about the constitution of a logistical and infrastructural assemblage that contains many diverse and dynamic material elements (cf Cowen 2010, Toscano 2011). Part of the specificity of the controversy over the construction of TAP, we suggest, derives from the interferences that occur between proximate subaquatic materials that are not readily integrated, either technically or legally, and that contribute to emergent and situated political effects (Barry 2013, Dittmer 2014).

\section{From Volume to Inter-Materiality}

A series of recent publications have issued growing calls for geographical research that addresses the geopolitical significance of what has variously been termed 'volume' or ‘verticality’ (e.g. Elden 2013a, Adey 2013, Graham and Hewitt 2013, Graham 2016, Squire 2017). This injunction has both conceptual and empirical implications.

Empirically, the idea that territories are three dimensional (Bridge 2013) directs geographers to consider the ways in which both the underground and the air have become historically, militarily and politically significant. Investigations of the military role of aerial photography, underground bunkers and tunnels by architectural theorists such as Paul Virilio and Eyal Weizman have been particularly influential in this respect (e.g. Virilio 1989, Weizman 2002, 2007) Indeed, the emerging focus on volume has suggested the need for a wide range of empirical studies of such aerial and subterranean practices as flying, diving and tunnelling, as well as the use of drones and satellites. Conceptually, it resonates with the argument that territories should not just be conceived 
as bounded areas but rather as spaces that have been formed and transformed in historically and geographically variable ways (Elden 2013b). Territories take diverse historical, political, legal and technical forms that may come to incorporate spaces below as well as above ground (Braun 2000). In short, territories have height and depth as well as surface; they have volume as well as area (Steinberg and Peters 2015).

We do not intend to review the emerging literature on volume in detail here, but we do note three ways in which accounts of the geopolitics of volume have been both developed and criticised. One line of critical commentary points to the empirical limitations of earlier work. Arguably, much of the literature on volume has focused on the military uses of both underground and above ground spaces. We agree with the urban geographer Andrew Harris when he observes: "it is also important to recognize forms, landscapes and experiences, as well as their associated rationales and logics, that are not necessarily a fall-out from warfare doctrines and military technoscience" (Harris 2015, 604); in this light, we suggest that existing debates would benefit from being supplemented by perspectives from research on underground natural resources, including minerals, gas and oil (Kama 2013, Valdivia 2015). A second line of argument is that studies that attend to volume need to address the ways in which bodies experience, are affected by and 'immersed' in underground and undersea spaces (Squire 2017). Moreover, there is growing interest in the 'elemental' qualities of materials, pointing towards the possibility of a 'post-phenomenological' analysis of both atmosphere and the underground (McCormack 2016). In a third line of commentary, the subterranean has to be understood as a space of geopolitical control: it is mapped, measured and 'rendered intelligible' by geoscientific and environmental measurements, assessments and models (Braun 2000, Kama 2013, Barry 2016a). 
In this paper, we take these developments further. Our argument starts from the recognition of the challenges that the subterranean and subaquatic routinely present to both government and capital including, in particular, the extractive industries (Barry 2013). To be sure, the subterranean and subaquatic are increasingly mapped and measured. Yet underground and undersea materials are nonetheless challenging to govern and control, generating their own dynamic (Clark 2011, Yusoff 2017). In theorising the ungovernability of subsurface materials, we might follow the work of the political theorist Jane Bennett, for whom material assemblages such as pipelines can be understood as a 'volatile mix' of elements that ultimately exceed any attempt to govern their behaviour. Her approach to the 'political ecology of things' thus places emphasis on 'the active role of nonhuman materials in public life' and the agency of nonhuman assemblages (Bennett 2010, see also Clark 2019).

The work of vital materialists including Bennett is instructive in drawing attention to the creative activity of nonhuman materials. As Philip Steinberg and Kimberley Peters rightly observe: "the vertical element introduced by scholars of volume is all too often abstract and dematerialised; the emphasis on materiality that typically is used to rectify this excess of abstraction tends to reproduce a sense of matter as fixed and grounded" (Steinberg and Peters 2015, 248). Yet, as Nicky Gregson and Bruce Braun have argued, while Bennett addresses the putative political agency of materials in general, her work provides a limited account of politics and history and, indeed, of the stability or ‘volatility' of particular inter-material relations (Gregson and Braun 2011, see also Barry 2013, chapter 7). We would offer three additional points. First, if subterranean and subaquatic materials have the activity and potential to matter geopolitically (Clark 
2019), the form and intensity in which they come to matter is both historically and geographically variable, and can only be determined in specific situations. Second, to understand the geopolitical significance of subterranean and subaquatic materials and organisms, we will suggest, it is necessary to address the ways in which the properties of materials become mediated and supplemented, although not controlled, by political, scientific and legal discourses and practices. Later in the paper we dwell in particular on the ways in which the relations between undersea organisms and materials come to be supplemented through the practices of environmental impact assessment and environmental law, amounting to what we have elsewhere called informed materials (Barry 2005, 2013, Bensaud-Vincent 1996, 206, Lloyd-Thomas 2010, cf Mol 2002). Third, and following on, any analysis of the politics of subterranean and subaquatic infrastructures, we contend, needs to attend to the unruly inter-material relations between infrastructures and their 'associated milieu' - that is, the environment of disparate materials and organisms in their proximity with which such infrastructures interfere (cf Simondon 2017, Massumi 2009). It should be clear, in this context, that we do not equate the idea of proximity simply with physical distance or depth. Rather, we understand proximity to refer to relations or interferences between things in their immediate environment that have the potential to have political, scientific or legal resonances elsewhere (Whitehead 1938, 140-141).

Present historical conditions, in which a concern with environmental impact has come to be integral to the performance of an'ethical capitalism', generate the potential for legal and scientific controversy (Barry 2013, 75). As the environmental lawyer Elizabeth Fisher has shown, assessments of environmental and social impact both address but also generate what she describes as "hot situations that are not just 'controversial'; they also 
have structural and foundational aspects" (Fisher 2016, 428-9). In short, the assessment of environmental impacts does not so much reduce the intensity of conflict about capitalism's uneven development as it provides a catalytic surface on which antagonistic disputes can foment - disputes that are often translated into a legal or quasi-legal form, and that invariably come to involve lay people as well as experts. In these circumstances, capitalism's politics may be articulated not just in relation to the molar politics of the state or political parties, but also the politics of specific environments such that lay people and counter-experts become involved in the production of knowledge about particular problems. As Philippe Pignarre and Isabelle Stengers suggest, in these ways the politics of capitalism tend to ignite around 'interstices' in which frictions may intensify (Pignarre and Stengers 2010, 110-115).

Our method in this paper dwells on some of the details of one interstice, which came to have much wider significance. To develop our analysis we draw, inter alia, on a vast body of documentation made public by the TAP company and their critics, on numerous reports in the Italian and international press, on interviews with critics of the project, scientific experts, interested and knowledgeable observers and company employees, and on participant observation of demonstrations in the vicinity of the pipeline construction site as well as of the work of NoTAP. Our contention is that by attending to both the conduct of political action and the interpretation of legal, scientific and corporate documents, it is possible to trace the shifting relations between the geopolitics of states and corporations and the material politics of subaquatic environments (Barry 2013, 2017). To this end, we carried out interviews and participant observation in San Foca, Lecce, Brindisi, and in the vicinity of the TAP construction site in late March and early April 2017 and returned to San Foca and Melendugno in October 2018 to participate in 
an international workshop on 'extractivism' that was supported by NoTAP and the Commune di Melendugno. ${ }^{7}$ Indeed, in our research, we came to be particularly informed by the scientific, political and legal practices of members of NoTAP. In this way, our analysis does not aspire to be symmetrical or disinterested, but takes inspiration from the perspectives and situated knowledge of some of the participants in the events themselves. ${ }^{8}$ In addition, we draw extensively on insights gathered from ongoing fieldwork, from 2004 onwards, on the construction of oil and gas pipelines in the Caucasus, including the Georgian section of both the Baku-Tbilisi-Ceyhan oil pipeline and Southern Gas Corridor, the South Caucasus Pipeline. ${ }^{9}$ Our contention is that by attending to the detail of the political situation, it becomes possible to trace the relations between the molar geopolitics of states, corporations and political parties and the minor geopolitics of marine environments, which would otherwise be indiscernible and invisible (Barry 2013, 2017). The case presented here is not intended as an 'instance' or illustration' of a particular claim about geopolitics (Berlant 2007). Rather, our fieldwork generated a theoretical effect, directing our analysis of the geopolitical significance of the subaquatic and subterranean in the pages that follow.

\section{From Party Politics to Geopolitics}

In the weeks preceding and following the rally on the beachfront of San Foca, mainstream media representations of the TAP controversy took an immediately recognisable form. The Melendugno dispute re-enacted a familiar confrontation between the police and protestors, or between agents of the state and political activists and environmentalists - which appeared to be centred on the fate of an ancient olive grove. ${ }^{10}$ For critical observers from the left, the dispute appeared familiar enough. The 
confrontation between protestors and police near Melendugno could be understood not just as a local dispute about the future of an olive grove but as a particular instantiation of global opposition to the activities of multinational energy companies. Local opposition was justified in this view because, although the Italian section of TAP was miniscule, it formed part of the wider infrastructure of fossil fuel capitalism (Shoraka 2017). From this perspective the Melendugno controversy was a dispute about the production of space and the reliance of a fossil fuel economy on the 'vertical' use of land, including the appropriation of agricultural land (cf Huber and McCarthy 2017). ${ }^{11}$ Indeed, protestors at Melendugno drew connections between their actions and those elsewhere in Europe and the USA. A banner held up at a rally in Lecce soon after the demonstration in San Foca read 'NoTAP/NoDAPL', creating an equivalence between the TAP protests and those surrounding the construction of the Dakota Access Pipeline. ${ }^{12}$ In this critical political framing, the removal of olive trees by the company was an index of the destructive environmental impact of the global fossil fuel industry; it was a sign from which abductive inferences about the activities of multinational energy companies in relation to the global politics of climate change could be drawn. The specific event should be understood within, and direct observers' attentions towards, a global political economic form. ${ }^{13}$

At the same time, the dispute in Melendugno and San Foca was also understood, in Italy at least, as an event primarily of national political significance. Arguably, this seemingly minor local dispute in the Salento attracted wider interest in Italy because it had become a vehicle for wider and established party political interests, figuring in the ongoing debates between the Partito Democratico (PD) government and its internal and external opponents - including the populist 5 Star Movement, who staged their own rally on San 
Foca beach independently of the NoTAP protest. ${ }^{14}$ Indeed, the Trans Adriatic Pipeline project had been considered by some to be vital not just for the EU, but also for Italy. A succession of Italian Prime Ministers - Prodi, Berlusconi, Monti, Letta and Renzi - had backed this private sector project since its inception in 2009 , reflecting the long-standing importance of transnational gas infrastructures in Italian politics. ${ }^{15}$ One informant added colour to this history. He reckoned that Prodi had seen TAP, in addition, as a way of stabilising the economic situation in Albania, thereby reducing the level of immigration across the Adriatic. Following the trilateral cooperation agreement signed between Italy, Greece and Albania in February 2013 (Azaria 2015, 24), the Italian government ratified the agreement through a constitutional decree that enshrined the strategic importance of TAP for the European energy market as a means of diversifying sources of supply, and as part of an investment in the "green and white economy" (Senato della Repubblica 2013, 15). The TAP company relied not only on the support of the Italian government in this project; it also enlisted the former UK Prime Minister Tony Blair to facilitate its progress (Doward 2014).

Against this background, the political scientist Andrea Prontera has argued that the TAP project can be understood as an index of a broader shift from an 'old' to a 'new' politics of energy security in Italy. In the new politics, the Italian state no longer acts through state ownership of key areas of the economy but performs what he calls a 'catalytic' role, supporting "companies that propose projects consistent with national energy policy goals" (Prontera 2018, 23). When the state takes on this catalytic function, the strategic importance of TAP for both Italy and the EU is affirmed, apparently establishing the basis for a predictable future that on which business can capitalise. ${ }^{16}$ In this context, the events in Melendugno and San Foca could also be interpreted as reproducing, through an 
alliance of state and capital, the exploitation of the Italian South, resonating with the long-standing 'Southern Question' in Italy: the historical experience of what Gramsci called "the old oppressions and exploitations of the Mezzogiorno" which, he argued, had been "reduced to the status of a semi-colonial market" (Gramsci 1971, 94, see also Gramsci 1994, 260).

Yet to view the TAP controversy simply as a vehicle for Italian party politics, or as a manifestation of wider global opposition to the fossil fuel industry, or as a sign of the catalytic yet contested role of the state, is too reductive - even if all these perspectives are a necessary part of our analysis. For none of these accounts is sufficient to explain why Melendugno, rather than anywhere else, had come to be the location of the Southern Gas Corridor and, therefore, could emerge as tactical point on the route. In addressing this problem, we begin with a question posed by one of our informants, a celebrated member of Sinistra Italiana (the Italian Left), who asked us why the TAP company had chosen to construct a major gas pipeline underneath a beach that would be packed throughout the summer with tourists? As she herself had diagnosed, the decision to locate the route of the pipeline through the municipality of Melendugno, which had come to be such a site of popular resistance, had proven politically to be an unwise decision. Citing Gramsci somewhat sardonically, and implicitly criticising the politics of Renzi's PD government, she observed that government should depend on the 'consent' of the people. In this respect, her criticism echoed the broader criticism of Renzi following his government's failure to win a referendum to reform the Italian constitution - a defeat that had led to his resignation in December 2016 (Bull 2017). Given this history, party political criticisms of the project were often linked directly or indirectly by national political opponents to broader criticisms of the 'post-ideological' Renzi 
government (Salvati 2016) and, in particular, to Renzi's proposed constitutional reforms - which threatened to significantly limit the role of the regions in the development of energy infrastructures, including TAP (Italy nd). Indeed the NoTAP committee, initially formed just by representatives of the municipality of Melendugno, had progressively drawn together a coalition of local mayors from across the political spectrum, who articulated the explicit opposition of the entire Salento region to the pipeline project. Following the removal of olive trees in the week after the NoTAP rally in San Foca, a poster for the campaign against Renzi's reform appeared on the wire mesh security fence that surrounded the pipeline construction site, a hand-written injunction that made the link between opposition to constitutional reform and opposition to TAP explicit: 'Il 4 Dicembre al referendum constituzionale vota No/Salento NoTAP':

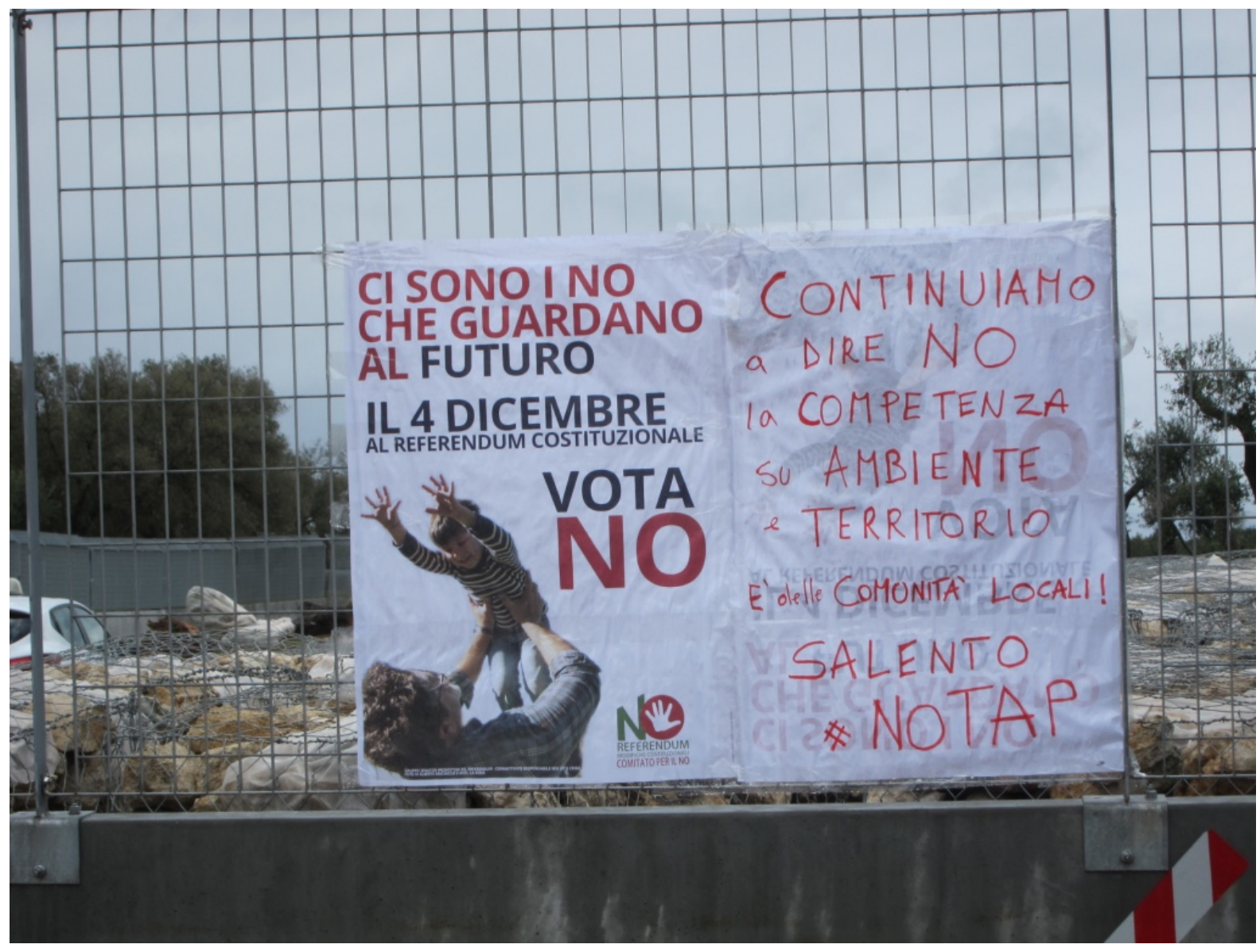

Figure 5. 'Il 4 Dicembre al referendum constituzionale vota No/Salento NoTAP', Melendugno, April 2017, photo: Andrew Barry. 
In responding to these criticisms from the left and municipalities in the Salento region, TAP company documents developed two related arguments. In effect, these documents finessed the critics by justifying the company's claim that the pipeline should be constructed in the proximity of San Foca primarily because it would have the least impact on the subaquatic marine environment. The company responded, first, that it had considered no less than eleven alternative sites, or 'feasibility sites', following the earlier intervention of regional President Michele Emiliano, who was in favour of a route near Brindisi. Indeed, in the days running up to the small rally in San Foca, the President of the region, Emiliano, a member of the PD but also an opponent of Renzi, claimed that an alternative route near the huge coal-fired power station of Cerano, south of Brindisi, was just as feasible. The TAP company responded to Emiliano by considering five different 'North Brindisi' options; but after an assessment process, the company rejected all of these alternative options, claiming that this was mainly due to the presence of the protected seagrass Posidonia Oceania offshore near Brindisi (TAP 2014c). The sociologist John Law has observed that decisions about important technoscientific projects may be understood as 'strategically and asymmetrically ordered performances that enact a distribution about what is to be acted as political and what is not' (Law 2002, 160-161). In this case, the company's decision, as it was articulated in its published accounts, enacted a clear distinction between the explicitly 'political' concerns of the region, on the one hand, and the 'non-political' interests of seagrass with which the company sought to align itself, on the other.

The second element of the TAP company's response to critics of the decision to select San Foca addressed the scientific and legal demands of marine nature conservation. 
Where alternative routes, such as in the vicinity of Brindisi, would pass through areas containing dense meadows of Posidonia Oceania, the density of Posidonia in the vicinity of San Foca was, according to the company's report, comparatively thin (TAP 2014e, 14). Hence, the coastline at San Foca was not protected from the construction of the pipeline because of the relative lack of Posidonia and, therefore, the absence of an offshore Marine Protected Area. The TAP company had formally consulted the public, and had therefore acted in line with both the principles set out in the Åarhus convention on public information disclosure and the EU directive on public access to environmental information. Despite these consultations, in the eyes of the TAP company, public and municipal concerns for the historical landscape of the Salento - for such things as olive trees, dry stone walls, and other aesthetic and historical elements of Salento's rural landscape - fell short of the demands meted out by marine nature conservation. ${ }^{17}$

The TAP company's justification for the San Foca route, which placed so much emphasis on the thin presence of Posidonia in the neighbourhood of San Foca, directs us towards the tension between two apparently contradictory aspects of European government. On the one hand, as the European Commission Vice-President had made clear, the construction of the pipeline was driven by a geopolitical vision: one that stressed the importance of energy security for the EU and the desire to consolidate a European Energy Union. But on the other hand, in parallel the EU was being progressively constructed as a harmonised space of environmental protection, a process that entailed the implementation of the EU Habitats Directive, the Marine Strategy Framework Directive and the Natura 2000 framework, which regulates the protection of subaquatic regions including parts of the Adriatic (Kay 2014). Posidonia Oceania beds were justifiably among the 'priority habitats' identified by the EU Habitats Directive 
(Telesca et al 2017) - after all, the subaquatic meadows of Posidonia "play a key role in protecting the coastline by trapping sediments, oxygenating the water and preventing coastal erosion” (European Commision 2009, 8, see also Agnesi et al 2008, Montefalcone et al 2009). Moreover, as a subsequent scientific review of the physical loss of Posidonia Oceania in Italian waters observed, the main human activities contributing to pressure on the seagrass are "coastal defence and ports, cables and pipelines” (Paganelli 2017, 7, our emphasis, Badalamenti 2006).

Indeed, with the exception of the coastline near to San Foca and Brindisi, alternative routes for the pipeline would have either directly or indirectly interfered with restrictions associated with Marine Protected Areas and regional nature reserve buffer zones (TAP 2014b, 32-33, TAP 2014d, European Communities 2009). Thus, although according to the company there were a number of other factors that influenced the choice of the best possible route - including onshore 'landscape restrictions' and considerations to do with the length of the pipeline between the compressor station in Albania and the pipeline receiving terminal (PRT) - the sparseness of Posidonia was the overriding factor (TAP 2014d, 42). As Stefan Bouzarovski and Marcin Konieczny argue, reflecting on the case of the Nordstream pipeline, the decision to construct an undersea rather than an underground onshore pipeline is likely to be simultaneously technical, financial and political, as it was in the case of TAP (Bouzarovski and Koniecny 2010, 10). For the company, "the route D1 (San Foca) [was therefore] the best alternative from the technical, environmental and landscape points of view" (TAP 2014d, 42). Furthermore, there were precedents: gas pipelines had previously been brought ashore in tourist areas further north on the Adriatic coast. In short, the geopolitical logic of EU energy security determined that the southern Adriatic was a good route for gas to flow into Europe; 
while, for the reasons detailed earlier, the governmental framework of European environmental protection determined that the pipeline should come onshore at San Foca rather than elsewhere on the Adriatic coast.

Considered against this background, San Foca was desirable as a location because it appeared to address or even resolve the apparent tension between the transnational government of marine ecosystems and the geopolitics of energy security. ${ }^{18}$ But in resolving this tension, the TAP pipeline could not simply come ashore at San Foca, immediately visible to the tourists who would come to the beach in large numbers in the summer months. According to the company, it would need to be contained in a $1.5 \mathrm{~km}$ long micro-tunnel that would start in the olive grove near the NoTAP occupation, pass underneath the beach, and end offshore (TAP 2104f, 16). The construction of a tunnel rather than a trench 'would allow interference with the coastal area' to be reduced, and in this way the apparent contradiction between the logic of EU energy security and EU environmental policy would be resolved by technical means (TAP 2017). Indeed, the subterranean and subaquatic construction of TAP is an index of what one might call the 'aesthetic governmentality' (Ghertner 2010) or environmental aesthetics of the modern petrochemical industry. This is an industry that in Western Europe has frequently sought to minimise its visibility to the public, seemingly merging into the natural environment in its vicinity, or aiming to recreate a 'natural' or 'original' landscape with which its activities are blended. Such an orientation was evident when the TAP company promised to return the olive trees of Melendugno to their original location once the pipeline had been built and buried (TAP 2014a, 44, cf Barry 2013, 116). The existing olive trees were not destroyed in the days following the San Foca protest, but uprooted, wrapped, taken away from the ancient grove and preserved, awaiting restoration at a later date. In effect, 
the subterranean and subaquatic would become part of what Sandro Mezzadra and Brett Nielsen $(2013,3-5)$ call an extended border zone, gathering together the symbolic, the legislative and the economic - one focused on a microtunnel constructed under the San Foca beach, the Adriatic seabed, and the aquifer underneath the olive groves of Melendugno.

\section{Subaquatic Materials}

It is clear that, thus far, the subterranean and subaquatic figure in two ways in the previous section. On the one hand, specific features of the subaquatic become objects of environmental government and protection (Bulkeley and Watson 2007). Hence, the offshore subaquatic environment is divided into a series of continuous and bounded territories or Marine Protected Areas, which have a legal status, and which are also networked with other areas through the Natura 2000 framework. In this context the undersea environment could be conceived as a 'volume' or zone that has depth and apparently clear boundaries, and which is secured for environmental protection (cf Elden 2013a, Steinberg 2016). On the other hand, the pipeline is also rendered subterranean, lying beneath both the beach and the olive groves, and thus out of sight, with the intention that the 'unnatural' impact of this industrial infrastructure on the landscape would, according to the company, be minimised (TAP 2014a, 6, TAP 2014f, 16).

However, the apparent resolution of the tension between the EU's commitment to both environmental protection and energy security was not as easy to achieve as the company might have imagined. As sociologists of science and technology have long argued, the production of knowledge claims - in this case about local environmental impacts and the 
construction of tunnels and pipes - can provoke as well as close down controversy (Barry 2002). The company may have hoped that its numerous feasibility studies, its commitment to the legal demands of public consultation, its corporate social responsibility programmes, and the constraints created by EU environmental law would, when taken together, have silenced its critics - or at least focused their attention on specific issues that the company could demonstrate its capacity to address and mitigate (Ifflander and Soneryd 2014). But in practice the opposite was the case. For each of the evidential and analytical claims made by the company about the pipeline's impact could be and were interrogated further, confirming Fisher's observation that the uncertain conclusions of environmental impact assessments invariably create the possibility for antagonistic 'hot situations' that may be very difficult to resolve (Fisher 2016, cf Callon, Lascoumes, and Barthe 2009).

Scientific reasoning had a central place not only in the TAP company's justifications but in the antagonistic politics generated by the San Foca siting of the pipeline. In the course of our fieldwork we interviewed a number of scientists, among them those who broadly supported NoTAP. These scientist informants raised a series of further questions about the relation between the construction of an underground pipeline and Posidonia Oceania as well as other subaquatic species. Here we summarise the arguments made by one or more of our informants about these subaquatic inter-material relations. First, there were many existing sources of deleterious environmental impact along the Adriatic coast, including a major highway and a railway line, car parks, and tourism facilities (Guido et al 2009). Out of season, before it had been cleaned up, the San Foca beach was littered with the debris of plastic bottles deposited by the marine currents that ran southwards along the western shore of the Adriatic, one manifestation of what has been termed the 
Mediterranean plastic soup'. In this light, the company might have overestimated the relative importance of the environmental impact of pipeline construction when there were already so many other major sources of environmental pollution along the Adriatic coast.

Moreover, Posidonia meadows, whether they exist in Marine Protected Areas or not, are likely to be far from uniform. The homogeneity of a Marine Protected Area, as a space of regulation, does not necessarily reflect a homogenous distribution in the species that the area is intended to protect. Marine Protected Areas inevitably have defined boundaries, and therefore 'volume', but these boundaries do not map exactly on to the distribution of Posidonia. In the view of one informant, the pipeline could have been routed through a Marine Protected Area at another location, and it would not necessarily have had any greater impact there than in San Foca. Indeed, it might even be argued that the presence of Posidonia Oceania near San Foca might have particular value because of its scarcity.

Other scientist informants noted further complications arising from the presence of more subaquatic species. For Posidonia Oceania was not the only significant element of the marine environment that deserved protection: this Italian stretch of the Adriatic also contained Cymodocea Nodosa. Moreover, in recent years Posidonia Oceania meadows have been threatened by the fast expansion of an 'alien' seagrass species, Caleurpa Raucemosa, which had spread through the Mediterranean from the Red Sea in the decades following the opening of the Suez Canal. Caleurpa thrives in conditions, such as polluted waters, that are unfavourable for Posidonia; once settled it is able to expand at a much faster rate than such protected species and tends to colonise neighbouring 
meadows, with the effect of suffocating the Posidonia (Piazzi et al 2001). Given the potentially negative impact of pipeline construction, the allegedly sparse Posidonia meadows in San Foca might well become further depleted, it was reasoned, favouring the expansion of Caleurpa Raucemosa. In short, the relative lack of Posidonia in the vicinity of San Foca had clearly affected the route of the pipeline; but in light of these subaquatic inter-material complexities, and the spread of Caleurpa Raucemosa it was unclear whether or how far this route was justified.

San Foca was attractive to the TAP company, however, not just because it was located on the coast at a point not protected by an offshore Marine Protected Area, but for other reasons - which also drew scientific contestation. It was, after all, one of the closest points on the Italian coast to Albania. A San Foca landing would minimise the length of offshore pipeline on Italian territory (TAP 2014d, 37), thereby minimising also the cost of expensive undersea construction. The reduction in the temperature of the gas as it crossed the Adriatic seabed would also be less than for other, longer routes, ${ }^{19}$ reducing the need to reheat the gas once the pipeline was connected to the Italian network although this route would have the additional effect of requiring further pipeline construction on Italian soil. The consequent need to construct a longer onshore length of pipeline generated further controversy. One of our scientist informants, Alessandro Manuelli, an engineer and a core member of NoTAP, questioned why there had not been any environmental and social impact assessment for the additional onshore section of the pipeline in Italy, which, although it would not be run by TAP, would be a necessary part of the pipeline system stretching all the way from Baku. He and other critics also questioned the plans for a station that would be constructed near the village of Melendugno, one designed to reheat the gas coming through the pipeline, when 
necessary, before it entered the wider Italian gas pipeline system. While the planned Melendugno station would not itself be underground, its construction was nonetheless necessary for the planned subsurface pipeline system to function as a whole. NoTAP argued that the Melendugno station was controversial because if the gas was heated there, then it could be regarded as an 'establishment' according to the terms of the EU 'Seveso' directive on 'the control of major accident hazards involving dangerous substances' (Renzoni 1977). In response, the company retorted that the Seveso directive did not apply to pipelines or to 'pumping stations' that would only occasionally be used to heat gas (European Union 2012). In this context, yet another dispute sprang up over whether the planned Melendugno station would be an 'establishment' or merely a 'receiving terminal' (TAP 2014a, 12), becoming the object of legal dispute.

In light of the above, it becomes clear that the subaquatic figures in four ways in the events surrounding the TAP, and not only in the two ways mentioned in the previous section. First, as we have noted, particular territories or 'volumes' become designated as spaces within which the marine environment is protected. In relation to TAP, such spaces are defined by EU environmental policy. Second, the pipeline is expected to be constructed underground, in part, to minimise its visible impact on the environment and the landscape above ground, thus conforming to the environmental aesthetic norms of the petrochemical industry. But the subaquatic figures also in two additional ways. On the one hand, the underground construction of the pipeline is nonetheless expected to have an impact on its immediate underwater environment, although the extent of this impact remains both uncertain and contested. On the other hand, the marine environment has its own spatiality that does not correspond either to the territory mapped out by the Natura 2000 framework or to the networked technical space of pipeline construction. 
Indeed, at a local level, “all seagrass species [including Posidonia Oceania] are rhizomatous, clonal plants, occupying space through the reiteration of shoots, with their leaves and roots produced as a result of rhizome extension" (Duarte 2002, 193). In this context, the subaquatic should be conceived of not just as a volume but as a site of situated encounters and inter-material relations and interferences between distinct assemblages that take diverse spatial forms - territorial, networked and rhizomic.

\section{Legal Symmetries}

As well as scientific knowledge, legal expertise came to play a key mediating role in the San Foca controversy. As legal geographers have long argued, legal practices are located; while legal reasoning takes distinct spatial forms, it is also situated in particular times and events, through practice (Blomley 1994, Bennett and Layard 2015). At the same time, as legal geographers remind us, legal practices contribute to the transformation of the relations between persons and things (Whatmore 2003). Both observations are relevant to the San Foca events. The practice of environmental law is expected to determine what relations between things and processes have an impact on the environment in their proximity (Fisher 2016). Yet the question of what such impacts are and what their spatiality is, in this case as in others, is contested and uncertain. But in addition, both the TAP company and NoTAP grounded their political claims in an appeal both to environmental law and, more broadly, to the value of legality in general.

In accounting for the benefits of the San Foca site, we have argued, the TAP company argued that it was guided by what it took to be legal considerations. San Foca was one location on the coast that was not protected by the existence of a Marine Protected Area; 
and TAP demonstrated the legality of its actions by following the legal process in this regard, having received the authorisation of the Italian government. However, at the rally at San Foca and elsewhere, members of NoTAP were equally insistent on the importance of legality; yet they mobilised the legal process in opposition to TAP. If the company justified their choice of San Foca with reference to the significance of Posidonia Oceania in European environmental law, TAP's opponents also drew attention to the legal significance of the site, which included the protection of Posidonia Oceania but - as we will show - much more besides.

Pursuing their own legal interventions, NoTAP took their action to the courts, recognising that even if the legal system could not stop the project, it could slow it down sufficiently to make it economically or politically unviable - particularly given that the pipeline was expected to become operational in 2020 (Holder 2004, 222). To this end, the Mayor of Melendugno supported the formation of a committee of counter-experts, with expertise in economics, engineering, law, and ecology (Comitato NoTap 2013, NoTap 2018). ${ }^{20}$ This committee went on to produce what might be called 'counterreports' to the company's reports. As a result, the dispute over the construction of the TAP pipeline in Melendugno became simultaneously more legal, more technical and more political (Latour and Weibel 2005). The 'major hurdle' that Melendugno presented was therefore not just a matter of local opposition to a pipeline construction project, nor solely to do with a defence of powers given to the regions by the Italian constitution, which Renzi hoped to rewrite. For at the same time, it revolved centrally around debates to do with the stability of the pipeline, its proximity to the rhizomic meadows of Posidonia Oceania, the composition of mud and sand, and the operation of underwater drilling machines and vehicles. While the Italian state had authorised the project in 2013, 
performing its catalytic function, and later deployed riot police to clear protestors from the olive grove, in practice the support of the state did not mean that the pipeline could necessarily be built. For the construction would also have to comply with the requirements of Italian environmental law and the specific 'prescriptions' for the pipeline construction produced by the Italian Ministry for Environmental Protection (Ministero dell Ambiente 2014), regulations that came to be energetically mobilised through by NoTAP's counter-experts as the project was progressively realised. To convey the quality and density of these regulations, we quote extracts from the relevant Italian environmental law prescriptions from 2014-15:

A4 (Ministry of Environment +ARPA) Regarding the underwater pipeline it is necessary to perform:

a. Chemical /physical and microbiological soil test.

b. These tests must be done in accordance with the regional environmental protection agencies (ARPA and ISPRA) and must comply with the Environmental Qualitative Standards (EQS).

A5 (Ministry of Environment +ARPA) Before proceeding with the construction of the microtunnel it is necessary to present an executive project which will have to undergo VIA assessment. This study will have to include thorough tests. In particular it is requested:

a. A detailed analysis of local currents in the offshore areas.

b. A morphological, sediment and stratigraphic analysis of the sea bed.

c. A chemical-physical analysis of the betonic muds. 
d. Ante-operam analysis of water murkiness (with ARPA and ISPRA).

e. Monitoring of the existing ecosystems and development of a protection plan esp. for Cymodocea Nodosa and Posidonia Oceania meadows.

According to the results a plan of actions, including different phases and monitorings, will have to be developed alongside ARPA and ISPRA.

A6 (Ministry of Environment) Regarding the trench:

a. A trench will only be allowed in the transition area and will have to be dug using a single machine (a crane backhoe dredger). This operation cannot exceed 60 days.

b. The exit point for the micro tunnel will have to be located 50 meters distant from the last plants of Cymodocea Nodosa.

c. The maximum width of the trench will have to be inferior to $35.0 \mathrm{~m}$.

d. The soil and materials which are excavated will have to be stored in an appropriate place and repositioned on the trench at the end of the works.

A7 (Ministry of Environment) Protection of Coral species:

a: Mapping though side-scan sonar technology for adjacents area measuring $400 \mathrm{~m}$ and distant $50 \mathrm{~m}$.

b: Underwater and above water monitorings.

A8 (Ministry of Environment + ARPA) Protection of the most prominent Coral species and bio-constructions. 
Classification, mapping and repopulation plans pre and post operam.

A9 (Ministry of Environment) In case of Coral formations or bioconstructions in the critical areas of the microtunnel and fibre optic cable construction it is necessary to reposition the structure maintaining a distance of at least 50 meters from the last formations.

A10 (Ministry of Environment) Regarding the operations of pipelaying it is prescribed:

The deployment of a remotely operated underwater vehicle that will grant a corridor of $\max 10 \mathrm{~m}$.

A14 (Ministry of Environment) Throughout the pipelaying works it is prescribed to redact an analysis assessing the stability of the pipeline up to a depth of $125 \mathrm{~m}$. This should be done in compliance with international norms.

A15 (Ministry of Environment) In case the analysis would suggest threats to the stability of any kind it is necessary to examine possible alternatives aimed at increasing the stability of the pipeline.

A16 (ARPA) The executive project will have to include a description of the composition of any materials used for the pipeline's and the microtunnel's construction. The materials will have to be approved by ARPA Puglia. 


\section{Ministero dell Ambiente (2014)}

While there is insufficient space to discuss all the issues raised by these multiple prescriptions, we want to make a general observation. The majority of prescriptions address specific challenges in bringing a pipeline onshore through the construction of a microtunnel at this site. They address, that is to say, the question of the interference between the pipeline construction and the realm of the subaquatic in its vicinity. The prescriptions concern, inter alia: the distribution and protection of coral and seagrass (Cymodocea Nodosa and Posidonia Oceania) species, and the proximity of the microtunnel to these species (A5-7); the stability of the tunnel up to a depth of $125 \mathrm{~m}$ (A14); the storage of excavated soil and materials (A6); the chemical composition of muds and pipeline materials (A5, A16); and the need for a 'morphological, sediment and stratigraphic analysis of the sea bed' as well as a 'detailed analysis of local currents' (A5). In this way, the prescriptions establish relations between things and processes - pipes, sand, seagrasses, mud, sea bed, currents, sedimentation, stability

- that are not defined in terms of area, volume or territory. Rather, the prescriptions define the relations between materials and processes in terms of their proximity and therefore their mutual interference and effects. In this light, the projected pipeline did not so much pass through a pre-existing 'volume' or territory (a Marine Protected Area); rather, the pipeline was projected as creating a new space defined both by the scope of its environmental and social impacts on other things and by other inter-material processes that happened to be in its vicinity - things and processes that it would affect and by which it would be affected. Through these regulations, science and the law joined hands in defining this emerging 
assemblage of complex inter-materialities, projecting its reality and thereby mediating any politics that might arise in relation to this new space.

In this respect, the political work of one of the most active and vocal participants in NoTAP, Alessandro Manuelli, himself an engineer, is instructive. For Manuelli mobilised aspects of Italian environmental law in order to contest the TAP company's claims on several grounds. In particular, he questioned whether it would be possible to construct the microtunnel at a distance of 50 meters 'from the last plants of Cymodocea Nodosa' given the technical limits of existing tunnelling technology (A6). In view of these limits, he argued, the pipeline would have to be built too close to this species of seagrass. He also contested whether the tunnel would be sufficiently stable (A15) in light of the fact that, according to his calculations, it would have to rest on sand and water. As he pointed out, while the company had set out a general case for the value of the microtunnel, they had not demonstrated unequivocally that, given the geology of the sea floor around San Foca, the microtunnel would provide a viable technical solution. ${ }^{21}$ From the point of view of the company, the microtunnel appeared to resolve several problems: how to bring the pipeline across the Adriatic coastline while minimising any disturbance to the presence of Posidonia, to the landscape of the coast of the Salento, and to the tourists for whom this landscape was so attractive. But for Manuelli the company's solution was no solution at all: because following the technical queries he had raised, because the construction of the microtunnel was neither practical nor legal due to the particular characteristics of the subaquatic environment in the vicinity of San Foca.

At the same time, the San Foca events generated a 'foundational' controversy about different forms and meanings of legality per se. On the one hand, the TAP company followed formal legal procedures, and the Italian state affirmed its right to make a decision on behalf of the 
greater good by positioning itself as the ultimate guarantor of legality. On the other hand, the opponents of TAP took their bearings from the Italian constitution - which survived the attempted reforms of the Renzi government. From their perspective, the Italian constitution was recognised as being both an expression and a guarantor of Italian democracy, while providing a potential bulwark against the policies and interests of any particular government. It was in this light that the opponents of TAP drew attention to what might be considered relatively mundane acts of illegality by the TAP company, notably its lack of compliance with health and safety at work legislation (Comitato NoTap 2017), as well as what the opponents saw as highly problematic links between the company and both the Azerbaijan state and the Azerbaijan state oil company, SOCAR. In this interpretation they drew support from investigative journalists writing for the national weekly news magazine, l'Espresso, who directed their readers to what they claimed were questionable aspects of the financing of the pipeline, pointing to corruption; indeed, in the journalists' account, it was a mafiadotto [mafia pipeline] (Biondani and Sisti 2017, see also Bankwatch 2016). Moreover, in 2016 the Extractive Industries Transparency Initiative questioned the transparency of the oil and gas economy in Azerbaijan because the Azerbaijan government "had not made satisfactory progress on requirement 1.3 on civil society engagement" (EITI 2016). In the following year, in March 2017, shortly before the demonstration in San Foca, "the Government of Azerbaijan decided to withdraw from EITI following its suspension by the EITI board on the previous day" (EITI 2017). In this case, just as Barry argues in relation to the Baku-Tbilisi-Ceyhan pipeline, the commitment of both corporations and states to transparency coexists with the proliferation of investigations and reports, as well as revelations and the circulation of 'public secrets' about what is thought to have not been rendered public. ${ }^{22}$ 
For the opponents of TAP, then, 'legality' was both constitutionally universal, above particular governments, and highly localised. It referred to the rule of democracy, nationally as well as internationally, but also to the 'legal' nature of their local struggle, which was simultaneously non-violent, technical, based on evidence, and opposed to the illegality of other powerful parties to the dispute. In their terms, they were engaged in an 'honest politics'. ${ }^{23}$ Indeed, it was in the effort to model or design such an 'honest politics' that the regional administration of Puglia, which came to be opposed to the San Foca route, sought to democratise the process of decision-making by bringing together counter-experts and nonexperts in order to discuss matters of collective concern (cf Callon, Lascoumes and Barthe 2009, Laurent 2016). In sum, for many of those who opposed the TAP pipeline the dispute did not just concern a pipeline, or the construction of a microtunnel, or the preservation of Posidonia. It was always, at the same time, about history and democracy, legality and illegality.

The controversy over the construction of TAP in Italy, as we have shown in the previous sections, was therefore never just one dispute. For it became a site of interference between multiple debates and vectors of contention - what one of us has termed a 'political situation' (Barry 2013, 16-17). These vectors and debates included those about the ongoing development of the ESIA as an element of environmental law, the imperatives of European energy security policy (Bridge 2015), the financing of the TAP project, the distribution of Posidonia and its relations with rival seagrasses, the recent history of public consultation and participation (Chilvers and Kearns 2016), the importance of olive trees to the economy and identity of the Salento, the question of constitutional reform, the future demand for gas in Italy, the technicality of microtunnel construction, the lived experience and political history of the Italian South, and, as we have seen, the relation between pipeline construction and 
subaquatic environment in its proximity. It is the political situation composed by this combination of debates, tendencies and inter-material relations, drawn together through the events in San Foca and Melendugno, that gave significance to this location as a tactical point in the Southern Gas Corridor.

\section{Conclusions}

In this paper we have highlighted the significance of the subaquatic environment to the controversy that erupted around the construction of the Trans Adriatic Pipeline near San Foca and Melendugno. To understand why this location emerged as a tactical point in the network, and why it became such a 'major hurdle' to the ambitions of the TAP company, the EU and the governments of Italy and Azerbaijan, we have indicated the need to attend to the role of a range of elements of the subaquatic environment. However, if the subaquatic played its part in the situation described here, we have stressed that it did not determine their course. The geopolitical significance of the subterranean and subaquatic is therefore not a given; it is, we suggest, a contingent achievement. The dynamism and flux of underground and undersea assemblages can come to matter geopolitically, but the circumstances in which they come to matter are also supplemented through practice (Barry 2013, 183, cf Clark 2019). In the case of San Foca, the inter-material relations between subaquatic materials and processes were mediated and supplemented by the contending, non-identical yet symmetrical legal and scientific practices informing the politics of both of the company and the Italian government and of NoTAP - the latter enacted in various kinds of counter-expertise and demonstration. In these circumstances, both those who promoted the construction of the pipeline and those who protested against its construction emphasised equally the legality of their arguments and the illegality of their opponents'. As we have seen, the controversy about the construction of TAP 
turns out to be a dispute that concerns the political and historical importance of legality in itself. But it is additionally a dispute about the legality of relations between disparate materials in a specific location that disrupts the construction of a pipeline. At this tactical point in the network, the process of rendering the pipeline invisible and under the surface itself became intensely visible, however briefly. In these ways the relations between subaquatic materials entered into escalating debates about the legality and democracy of a carbon economy 'in transition'.

While there is an inevitable contingency to the political situation described here, which encompasses many distinct vectors of contention, the case of TAP nonetheless allows us to draw wider conclusions about the subterranean and subaquatic. We have questioned the idea that the subterranean and subaquatic should be understood primarily as a realm of 'vertical' territory or volume. For while a focus on verticality has been valuable for those concerned with the analysis of geopolitics, there is also a need to attend to the relations between subsurface materials and organisms that are not contained or defined by territory or volume. We have noted, inter alia, the importance of the invisibility of pipes to the environmental aesthetics of the oil and gas industry, the co-existence and competition between different species of seagrass along the Adriatic coastline, and the potential tension between the construction of pipelines as networks and as underground and undersea infrastructures, which only becomes manifest at specific points. And we have highlighted the ways in which disparate subaquatic materials and organisms, including a microtunnel and several species of seagrass, have their own rhizomic inter-materialities. The subaquatic turns out to be a space of interferences between disparate materials and processes that both resist and assist efforts to govern or contain them. Through the mediation of scientific, legal and political practice, the proximity of subaquatic materials can come to acquire remarkable geopolitical significance. 


\section{Acknowledgements}

Our thanks to all our informants, including members of NoTAP, without whom this project would not have been possible. We would also like to thank Kärg Kama, Elizabeth Fisher, Georgina Born, Rachael Squire, Klaus Dodds and two anonymous reviewers for their insightful comments on an earlier draft of this paper. The argument has benefited from discussions following lectures and seminars at the University of Frankfurt, Oxford University, the Free University of Tbilisi, UCL, and New School University, New York, at which aspects of this research project were presented.

\section{References}

Abourahme, N. and O. Jabary-Salamanca. 2016. Thinking about the Sovereignty of the concept: a conversation with Timothy Mitchell. City 20 (5): 737-754.

Adey, P. 2013. Air. London: Reaktion Books.

Albanese, C. 2018. The 1600 Olive Trees Holding Up a \$5.2 billion Pipeline. Bloomberg news, July 5.

Agnesi, S, M. Cassese, G. Mo, and L. Tunesi. 2008. Sites of Community Importance for Posidonia Oceania: tools for conservation in Italy, Biol. Mar. Mediterr, 15 (1): 298-299. Agnew, J. and M. Shin. 2017. Spatializing Populism: Taking Politics to the People in Italy. Annals of the Association of American Geographers 107 (4): 915-933.

Azaria, D. 2015. Treaties on Transit of Energy via Pipelines and Countermeasures. Oxford: Oxford University Press.

Badalamenti F., G. Di Carlo, G. D’Anna, M. Gristina and M. Toccacelli. 2006. Effects of dredging activities of population dynamics of Posidonia Oceania (L.) Delile in the 
Mediterranean Sea, the case study of Capo Feto (SW Sicily, Italy). Hydrobiologica 555: 253261.

Bankwatch. 2016. Risky Business: who benefits from the Southern Gas Corridor, https://bankwatch.org/risky-business

Barry, A. 2002. The anti-political economy. Economy and Society 31 (2): 268-84.

Barry, A. 2005. Pharmaceutical Matters: the invention of informed materials, Theory, Culture, and Society 22 (1): 51-69.

Barry, A. 2013. Material Politics: Disputes along the Pipeline, Chichester: Wiley-Blackwell. Barry, A. 2015. The Oil Archives, In Subterranean Estates: Life Worlds of Oil and Gas, eds. H. Appel, A. Mason and M. Watts, 95-107. Ithaca: Cornell University Press.

Barry, A. 2016a. Infrastructure and the Earth. In Infrastructures and Social Complexity. Eds. P.Harvey, C.B. Jensen, and A. Morita, 168-178. London: Routledge.

Barry, A. 2016b. Infrastructures made Public. Limn 7.

Barry, A. 2017. Minor Political Geographies. Environment and Planning D: Society and Space 35 (4): 589-592

Battaglia, A. 2017. Gasdotto Tap, Democrazia alla Canna del Gas. Il Governo contro I Sindaci e I Cittadini. http://temi.repubblica.it/micromega-online/gasdotto-tap-democraziaalla-canna-del-gas-il-governo-contro-sindaci-e-cittadini/.

Beck, U. 1992. Risk Society, London: Sage

Bennett, J. 2010. Thing-Power. In Political Matter: Technoscience, Democracy, and Public Life, eds. B. Braun and S. Whatmore, 35-62. Minneapolis: Minnesota University Press Bennett, L. and Layard, A. 2015. Legal Geography: Becoming Spatial Detectives. Geography Compass 9(7): 406-22

Berlant, L. 2007. On the case, Critical Inquiry 33 (4): 663-672. 
Bensaude-Vincent, B. and I. Stengers. 1996, A History of Chemistry. Cambridge, MA: Harvard University Press.

Biondani, P. Sisti, L. 2017. The Pipeline of the Three Regimes, L'Espresso available at http://espresso.repubblica.it/inchieste/2017/04/18/news/the-pipeline-of-the-three-regimes1.299786 (last accessed 16.10.2017).

Blomley, N. 1994. Law, space, and the geographies of power. New York: Guilford Press. Born, G. 2007. Future-making: corporate performativity and the temporal politics of markets, In Cultural Politics in a Global Age: Uncertainty, Solidarity and Innovation. ed. D. Held and H. Moore, 288-296. London: Oneworld.

Bosse, G. 2011. The EU's Geopolitical Vision of a European Energy Space: When 'Gulliver' meets 'White Elephants' and Verdi's Babylonian King. Geopolitics 16 (3): $512-$ 535.

Bouzarovski, S., M. Bradshaw, and A. Wochnik. 2015. Making Territory through infrastructure: the governance of natural gas transit in Europe. Geoforum, 64: 217-228. Bouzarovski, S. and M. Konieczny 2010. Landscapes of Paradox: Public Discourses and Policies in Poland's Relationship with the Nord Stream Pipeline. Geopolitics 15 (1): 1-21. Braun, B. 2000. Producing Vertical Territory: Geology and Governmentality in Late Victorian Canada. Cultural Geographies 7 (1): 7-46.

Bridge, G. 2013. Territory, now in 3D! Political Geography 34: 55-57.

Bridge, G. 2015. Energy (in)security: world-making in an age of scarcity The Geographical Journal 181 (4): 328-339.

Bulkeley, H. and M. Watson. 2007. Modes of Governing Municipal Waste. Environment and Planning A, 39: 2733-2753.

Bull, M. 2017. Matteo Renzi just killed off Italy's Centre Left The Conversation, $23^{\text {rd }}$ February 
https://theconversation.com/matteo-renzi-just-killed-off-italys-centre-left-73492

Callon, M., P. Lascoumes and Y. Barthe. 2009. Acting in an Uncertain World: an Essay on Technical Democracy. Cambridge, MA: MIT Press.

Cancellato, F. 2017. Tragicomico Sud. La Protesta Insensata Contro il Gasdotto Tap in Puglia. http://www.linkiesta.it/it/article/2017/03/30/tragicomico-sud-la-protesta-insensatacontro-il-gasdotto-in-puglia/33708/

Chilvers, J., and M. Kearns eds. 2016. Remaking Participation: science, environment and emergent publics, London: Routledge.

Clark, N. 2011. Inhuman Nature: sociable life in a dynamic planet, London: Sage

Clark, N. 2019. Meetings with Magma: Three Political Geologies. In Political Geology:

Active Stratigraphies and the Making of Life. Eds. Bobbette, A. and Donovan, A.

Basingstoke: Palgrave Macmillan.

Comitato NoTap (2013) 'Cosa e' il TAP Spiegato da Tre Illustri Esperti', No Transadriatic Pipeline Blog. Available at [online]

https://notransadriaticpiperline.blogspot.com/2013/12/cosa-e-tap-spiegato-da-tre-illustri.html [last accessed 30.01.2019].

Cowen, D. 2010. A Geography of Logistics: Market Authority and the Security of Supply Chains', Annals of the Association of American Geographers 100 (3): 600-620.

Diani, M. 1995. Green Networks: a Structural Analysis of the Italian Environmental Movement. Edinburgh: Edinburgh University Press.

Dittmer, J. 2014. Geopolitical Assemblages and Complexity. Progress in Human Geography, 38: $385-401$.

Doward, T. 2014. Tony Blair will advise on controversial gas pipeline from Azerbaijan to Italy. The Observer, August 2.

Duarte, C. 2002. The future of seagrass meadows. Environmental Conservation 29: 193 
EITI (Extractive Industries Transparency Initiative). 2016. Azerbaijan: 2016 validation. Oslo: Extractive Industries Transparency Initiative. https://eiti.org/validation/azerbaijan/2016 (last accessed January 2019).

EITI. 2017. Status of Azerbaijan. https://eiti.org/azerbaijan (last accessed January 2019).

Elden, S. 2013a. Secure the Volume: Vertical Geopolitics and the Depth of Geopower.

Political Geography, 34: 35-51

Elden, S. 2013b. The Birth of Territory. Chicago: Chicago University Press.

European Commission. 2009. Natura 2000 in the Mediterranean Region. Luxembourg:

Office for Official Publications of the European Communities.

European Commission. 2015. Prolonging the exemption of the Trans-Adriatic Pipeline from certain requirements on third party access.

https:/ec.europa.eu/energy/sites/ener/files/documents/2015_tap_prolongation_decision_en.p $\underline{\mathrm{df}}$

European Commission. 2017. Vice-President Šefčovič attends Southern Gas Advisory Council meeting. https://ec.europa.eu/energy/en/news/vice-president-

\%C5\%A1ef\%C4\%8Dovi $\% \mathrm{C} 4 \% 8 \mathrm{D}$-attends-southern-gas-advisory-council-meeting (accessed January 2019)

European Parliament. 2009. Gas and oil pipelines in Europe. Briefing note PE 416.239, Luxembourg: European Parliament.

European Union. 2012. Directive 2012/18/EU of the European Parliament and the Council: on the control of major-accident hazards involving dangerous substances, amending and subsequently repealing Council Directive 96/82/EC. Official Journal of the European Union, July 24. 
Fisher, E. 2006. 'Unpacking the Toolbox: or why the public/private divide is important in EC Environmental Law', in The Public Law/Private Law Divide: une entente assez cordiale. eds. M. Freedland and J-B. Auby. London: Hart.

Fisher, E. 2016. Environmental Impact Assessment: 'Setting the Law Ablaze'. In Research Handbook on Fundamental Concepts of Environmental Law. (ed.) Douglas Fisher. Cheltenham: Edward Elgar.

Fisher, E., B. Lange, and E. Scotford eds. 2013. Environmental Law: Texts, Cases, Materials, Oxford: Oxford University Press.

Ghertner, D. 2010. Calculating without numbers: aesthetic governmentality in Delhi's slums. Economy and Society 39 (2): 185-217.

Graham, S. 2016. Vertical: the City from Satellites to Bunkers, London: Verso.

Graham, S and L Hewitt 2013. Getting off the ground: the politics of urban verticality. Progress in Human Geography 37 (1): 72-92.

Gramsci, A. 1971. Notes on Italian History. In Selections from Prison Notebooks, 52-120. London: Lawrence and Wishart.

Gramsci, A. 1994. The Mezzogiorno and Fascism. In Pre-Prison Writings, 260-264. Cambridge: Cambridge University Press.

Gregson, N. and Braun, B. 2011. Book review forum, J. Bennett, Vibrant Matter: A Political Ecology of Things. Dialogues in Human Geography 1 (3): 390-405.

Guido, M; Lomoro, A; Montesano, F; Parente, A; Zini, A. 2009. P.R.I.M.E. Posidonia Residues Integrated Management for Eco-sustainability http://ec.europa.eu/environment/life/project/Projects/index.cfm?fuseaction=home.showFile\&

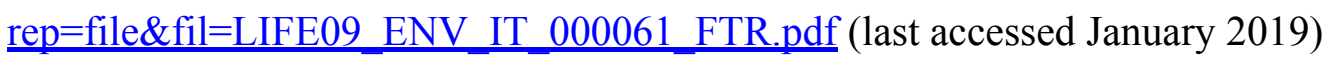
Haraway, D. 1997.Modest Wtiness@Second_Millennium.FemaleMan_Meets_OncoMouse, London: Routledge. 
Harris, A. 2015. Vertical urbanisms: opening up geographies of the three dimensional city. Progress in Human Geography 39 (5) : 601-620.

N. Heynen and L. Van Sant. 2015. Political Ecologies of Activism and Direct Action Politics. In The Routledge Handbook of Political Ecology, ed. T. Perreault, G. Bridge and J. McCarthy, 169-178. London: Routledge.

Holder, J. 2004. Environmental Assessment: the Regulation of Decision-Making. Oxford: Oxford University Press.

Huber, T. and J. McCarthy. 2017. Beyond the subterranean energy regime? Fuel, land use and the production of space Transactions of the Institute of British Geographers 42 (4): 655668.

Huffington Post. 2017. Caos et Proteste per il gasdotto TAP. L'Huffington Post. March 20. Italy (nd) Constitution of the Italian Republic.

Ifflander, H and L Soneryd. 2014. The relative power of environmental assessment as a governance tool: organization and the case of the Nord Stream gas pipeline. Impact Assessment and Project Appraisal 32 (2): 98-107.

Kama, K. 2013. Unconventional futures: anticipation, materiality and the market in oil shale development. DPhil diss., University of Oxford.

Kama, K. 2016. Contending geo-logics: energy security, resource ontologies, and the politics of expert knowledge in Estonia. Geopolitics 21 (4): 831-856

Kay, K. 2014. Europeanization through biodiversity conservation: Croatia's bid for accession and the Natura 2000 process. Geoforum 54: 80-90.

Latour, B., and P. Weibel eds. 2005. Making Things Public: Atmospheres of Democracy, Cambridge, MA: MIT press.

Laurent, B. 2016. Political Experiments that Matter: Ordering Democracy from Experimental Sites. Social Studies of Science 46 (5): 773-794. 
Law, J. 2002. Aircraft Stories: Decentering the Object in Technoscience. Durham, NC: Duke University press.

Lee, M. 2005. EU Environmental Law, Governance and Decision-Making, London: Hart. Lloyd-Thomas, K. 2010. Building Materials: Conceptualising Materials via the Architectural Specification. PhD diss., Middlesex University.

Makholm, J. 2012. The Political Economy of Pipelines. Chicago: Chicago University Press. Massumi, B. 2009. Technical Mentality revisited, interview with A. de Boever, A. Murray, and R. Joffe. Parrhesia 7: 36-45.

McCormack, D.P. 2016. Elemental infrastructures for atmospheric media: on stratospheric variations, value and the commons. Environment and Planning D: Society and Space 35 (3): 418-37.

Ministero dell Ambienete (Ministero dell Ambiente della Tutela del Territorio e del Mare). 2014. D.M. 0000223. Gasdotto Denominato 'Trans Adriatic Pipeline per il Transporto in Italia di Gas del Mar Caspio Attraverso Grecia e Albania - Societa TAP AG Italia. http://www.va.minambiente.it/it-IT/Oggetti/MetadatoDocumento/114312 (last accessed January 2019).

Mitchell, T. 2011. Carbon Democracy: Political Power in the Age of Oil. London: Verso. Mol, A. 2002. The Body Multiple: Ontology in Medical Practice. Durham, NC: Duke University Press.

Montefalcone, M., G. Albertelli, C. Morri, V. Parravicini and C.N. Bianchi. 2009. Legal Protection is not enough: Posidonia Oceania meadows in marine protected areas are not healthier than those in unprotected areas of the northwest Mediterranean Sea. Marine Pollution Bulletin 58 (4): 515-519.

No Tap (2018) Chi Siamo, NoTap. Available at [online] https://www.notap.it/chi-siamo/ [last accessed 30.01.2019] 
Peet, R., and M. Watts eds. 2004. Liberation Ecologies: Environment, Development and Social Movements. London: Routledge.

Paganelli, D., P. La Valle, M. Pulcini, and R. Proietti. 2017. Towards an evaluation of physical loss pressure in the Italian seas for the implementation of the marine strategy framework directive. Journal of the Marine Biological Association of the United Kingdom, 98 (1): 61-69. doi: 10.1.1017/S0025315417000911.

Piazzi, L; Ceccherelli, G; Cinelli, F. 2001. Threat to Macroalgal Diversity: Effects of The Introduced Green Alga Caulerpa Racemosa in the Mediterranean. Marine Biology Progress Series. 210: 149-159.

Pignarre, P. and I. Stengers. 2010. Capitalist Sorcery: Breaking the Spell, Basingstoke: Palgrave Macmillan.

Pirani, S., J. Stern, and K.Yafimava. 2009. The Russia-Ukraine gas dispute of January 2009: a comprehensive assessment. Oxford: Oxford Institute of Energy Studies.

Poti, M. 2017. Tap, parla il sindaco di Melendugno. La Stampa. March 29. https://www.lastampa.it/2017/03/28/italia/tap-parla-il-sindaco-di-melendugnoxdO9jTwkzQGqCkR9zvDr0O/pagina.html (last access January 2019) Prontera, A, 2018. Italian energy security, the Southern Gas Corridor and the new pipeline politics in Western Europe: from the partner state to the catalytic state. Journal of International Relations and Development 21 (2): 464-494.

Puglia. 2013. Open consultation led by the Puglia Region Il Gasdotto TAP e La Puglia http://partecipazione.regione.puglia.it/, see also http://participedia.net/de/node/5005 Renzoni, A. 1977. 'The Increasing Number of Environment-degrading Accidents in Italy', Environmental Conservation 4 (1): 21-26

Reuters 2017. Top policymakers reassure Europe on Azeri gas deadline. February $23^{\text {rd }}$, http://uk.reuters.com/article/uk-italy-tap-idUKKBN1620JG, our emphasis. 
Salvati, E. 2016. Matteo Renzi: a new Leadership style for the Italian Democratic Party and Italian Politics. Modern Italy 21 (1): 7-18.

Senato della Repubblica (2013) Disegno di Legge Ratifica ed Esecuzione dell'accordo tra la Repubblica di Albania, la Repubblica Greca e la Repubblica Italina sul Progetto "Trans Adriatic Pipeline", fatto ad Atene 13 Febbraio.

Shoraka, S. 2017. A southern Italian village's fight against the fossil fuel industry', Open Democracy, 31 March, https://www.opendemocracy.net/can-europe-make-it/sarah$\underline{\text { shoraka/south-italian-villages-fight-against-fossil-fuel-industry }}$ (last accessed 30.1.19)

Shiriyev, Z. 2017. Oil Price and Russian Pressure put Azerbaijan's strategic gas project at risk.

https://www.chathamhouse.org/expert/comment/oil-price-and-russian-pressure-putazerbaijan-s-strategic-gas-project-risk

Siddi, M. 2017. The EU's Botched Geopolitical Approach to External Energy Policy: The Case of the Southern Gas Corridor. Geopolitics DOI: 10.1080/14650045.2017.1416606

Simondon, G. 2017. The Mode of Existence of Technical Objects. Minneapolis, MN: Univocal.

Squires, N. 2017. Olive Groves in Italy become battleground over controversial gas pipeline. Daily Telegraph, March 29.

Squire, R. 2017. Do you dive? Methodological considerations for engaging with "volume". Geography Compass 11 (7) DOI: 10.1111/gec3.12319

Steinberg, P. and K. Peters. 2015. Wet ontologies, fluid spaces: giving depth to volume through oceanic thinking. Environment and Planning D 33 (2): 247-264.

TAP (Trans Adriatic Pipeline). nd. The Southern Gas Corridor. https://www.tap-ag.com/thepipeline/the-big-picture/southern-gas-corridor 
TAP. 2014a. ESIA Italy - Section 4 Project Description.

TAP. 2014b ESIA Italy - Annex 2 Alternative Assessment.

TAP. 2014c. ESIA integrations: Annex 3 Replies to the Observations of the Public.

TAP. 2014d. ESIA integrations: Annex 4 Alternative Assessments.

TAP. 2014e. Appendix 12 - Posidonia Report.

TAP. 2014f Project Basic Design - Italy

TAP (2017) Prescrizione A.11. Manuale Operativo per la Costruzione Approdo e la Posa del Gasdotto a Mare. IPL00-PMT-000-G-TMO-001. 66-81. http://www.va.minambiente.it/itIT/Oggetti/Documentazione/625/2848 (last accessed January 2019).

Taussig, M. 1999. Defacement: public secrets and the labor of the negative. Stanford: Stanford University Press.

Telesca, L. et al. 2017. Seagrass meadows (Posidonia Oceania) distribution and trajectories of change. Nature Scientific reports 5: 12505, 2-14.

Toscano, A. 2011. Logistics and Opposition. Mute 3 (2)

http://www.metamute.org/editorial/articles/logistics-and-opposition

Tsing, A. 2005. Friction: an ethnography of Global Connection. Princeton: Princeton University Press.

Valdivia, G. 2015. Oil frictions and the subterranean geopolitics of energy regionalisms. Environment and Planning A 47 (7): 1422-1439.

Viesti, G. 2017. Renzi ha Tagliato gli Investimenti al Sud per Finanziare il Jobs Act. https://ilmanifesto.it/login

Virilio, P. 1989. War and Cinema: the Logistics of Perception. London: Verso.

Watts, M. 2004. Resource curse? Governmentality, oil and power in the Niger Delta, Nigeria Geopolitics, 9 (1): 50-80. 
Whatmore, S. 2003. De/re-territorializing possession: the shifting spaces of property rights. In Law and Geography, ed. J. Holder and C. Harrison, 211-224. Oxford: Oxford University Press.

Weizman, E. 2002. Introduction to the Politics of Verticality. https://www.opendemocracy.net/ecology-politicsverticality/article 801.jsp Weizman, E. 2007. Hollow Land: Israel's Architecture of Occupation. London: Verso. Whitehead, A.N. 1938. Modes of Thought. New York: The Free Press.

Wilson, A. 2014. Ukraine Crisis: what it means for the West. New Haven and London: Yale University Press.

Yusoff, K. 2017. Geosocial Strata. Theory, Culture, and Society 34 (2-3): 105-127. 
${ }^{1}$ Here and throughout we use the term network descriptively to refer to the pipeline network rather than as a theoretical or analytical concept.

${ }^{2}$ We adapt the idea that disparate things may generate emergent effects broadly from Gilbert Simondon (Massumi 2009).

${ }^{3}$ From our field notes, March 2017.

${ }^{4}$ On the analysis of projections of corporate futures see Born 2007.

${ }^{5}$ The events were very widely covered in the press and on social media both in Italy, and to a lesser extent, internationally. See, for example, Poti 2017, Huffington Post 2017, Squires 2017.

${ }^{6}$ On the formation of environmental social movements in Italy, see Diani 1995.

${ }^{7}$ The workshop on Policing Extractivism: Security, Accumulation, Pacification (5-7 October 2018) was co-organised by the Università del Salento, the Associazione Bianca Guidetti Serra, and the Transnational Institute, and supported by NoTAP and the Commune di Melendugno. It occurred in the midst of a later phase in the controversy, following the decision by the Italian coalition government to not cancel the construction of the pipeline, even though the Five Star Movement, which now formed part of the coalition government, had been opposed to the project prior to the 2018 general election. One of the central disputes in this later phase concerned the scale of the penalties that would have to be paid to the company if the project were to be cancelled. Our thanks to NoTAP for inviting one of us (Andrew Barry) to attend the workshop.

${ }^{8}$ On the notion of situated knowledge see, in particular, Haraway, D. (1997).

${ }^{9}$ In total, one of us (Andrew Barry) has carried out seven periods of fieldwork, each lasting between two and six weeks, on the politics of energy infrastructure in Georgia including the BTC oil pipeline. This research has involved well over 100 interviews with officials working 
for national governments and international financial institutions, consultants, academic scientists, company managers, journalists, activists, and members of communities affected by construction work (Barry 2013). In another paper, Andrew Barry explores the geopolitical significance of subterranean materials in the Georgian case (Barry 2016a).

${ }^{10}$ In the UK press see, for example, Doward, T 2014, Squires 2017. Italian press coverage was extensive and highlighted the significance of the national political context see, for example, Cancellato 2017, Battaglia 2017, and Viesti 2017.

${ }^{11}$ In this case, there was little controversy about the level of land compensation unlike, for example, in Georgia and Azerbaijan during the construction of the earlier BTC pipeline, see Barry 2013, chapter 8 .

${ }^{12}$ From our fieldnotes, Sunday $2^{\text {nd }}$ April 2017, Lecce. NoDAPL refers to the controversy surrounding the construction of the Dakota Access Pipeline.

${ }^{13}$ On the role of abductive inference in politics see Barry $(2013,84)$. On the link between this local event and globalization see, for example, Albanese 2018.

${ }^{14}$ John Agnew and Michael Shinn have observed that the promise of the 5 Star Movement is of a politics without "institutional or geographical" mediation, but this "promise cannot be fulfilled [in Italy]' (Agnew and Shinn 2017: 930). Their conclusion about the impossibility of a politics without institutional or geographical mediation was arguably born out by the decision of the Five Star Movement, once it entered government, not to cancel TAP (see note 7).

${ }^{15}$ Despite pressure from the US government, gas pipelines had previously been constructed between Sicily and both Tunisia/Algeria and Libya.

${ }^{16}$ Here we allude to the idea of capitalization suggested by Timothy Mitchell: "the idea of capitalization points to a particular way of rendering the future available in the present. It refers to a way of building durable structures of accumulation where a certain amount of 
the income that can be expected in the future is sold to investors in the present" (Abourahme and Jabary-Salamanca 2016, 740, Barry 2016b).

${ }^{17}$ On public information disclosure in the EU see Lee, M. (2005, 190-191) and Fisher (2013, 200).

${ }^{18}$ Elizabeth Fisher observes that "both [the Wild Birds and Habitats Directive]...give very little room to balance other factors with nature conservation and thus problems of divergent views are largely characterized as implementation problems” (Fisher 2006, 223).

${ }^{19}$ Because of the Joule-Thomson effect, linking pressure and temperature changes.

${ }^{20}$ The term 'counter-expertise' is used by Ulrich Beck 1992.

${ }^{21}$ Interview with Alessandro Manuelli, San Foca, April 2017 and Manuelli, A. 2017. Analisi Progetto TAP, presentation, Università del Salento, Lecce.

${ }^{22}$ The term public secret is used by Michael Taussig (1999) to refer to those 'secrets' that are not officially public, but everyone knows, which may or may not be true.

${ }^{23}$ According to one participant in the consultation process organised by the regional government (Puglia 2013). 